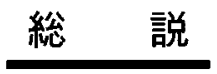

\title{
可溶化の電気化学的制御
}

\author{
酒井 秀樹*1,*2.阿部 正彦*1,*2 \\ $* 1$ 東京理科大学理工学部工業化学科 \\ （开278-8510 千葉県野田市山猗 2641） \\ *2 東京理科大学界面科学研究所 \\ (₹162-8601 東京都新宿区神楽坂 1-3)
}
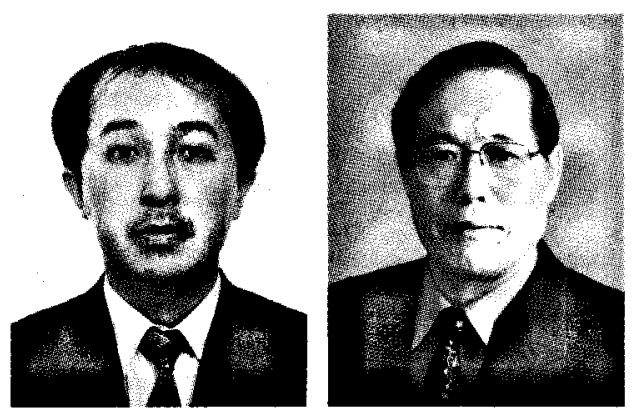

\section{Electrochemical Control of Solubilization by Redox-Active Surfactants}

\author{
Hideki SAKaI ${ }^{* 1,2}$ and Masahiko ABE ${ }^{* 1,2}$ \\ * 1 Faculty of Science and Technology, Science University of Tokyo \\ (2641 Yamazaki, Noda-shi, Chiba-ken 278-8510) \\ *2 Institute of Colloid and Interface Science, Science University of Tokyo \\ (1-3 Kagurazaka, Shinjuku-ku, Tokyo 162-8601)
}

\begin{abstract}
The solubilization of organic molecules in surfactant molecular assemblies may be controlled effectively by electrochemical reactions using redox-active surfactants. In this study, several aromatic compounds were solubilized in aqueous micellar solution of ferrocene-modified nonionic surfactant (11-ferrocenylundecyl polyoxyethylene ether : FPEG) and the effects of redox reactions on solubilization were examined. The solubilization equilibrium constant $(K)$ of the solutes in FPEG micelles, which represents the distribution of solubilizates between micelles and bulk solution, was noted to decrease with the oxidation of ferrocenyl moieties of FPEG molecules, but increase with reduction of ferrocenyl moieties. Electrochemical control of vesicle formation and applications for solubilization control were investigated using aqueous mixtures of a ferrocenemodified cationic surfactant (FTMA) and anionic sodium dodecylbenzene sulfonate (SDBS).

Key words : solubilization, ferrocene, redox reactions, micelle, vesicle
\end{abstract}

\section{1 はじめに}

界面活性削が有する重要な特性の一つに，ミセル・ベ シクルなどの分子集合体の形成，ならびに集合体内部へ の水難溶性物質の溶解（可溶化）がある。可溶化とは, 溶媒に難溶性の物質（被可溶化物質）が, 界面活性骼が 形成する分子集合体内部へ取り込まれ，熱力学的に安定 で等方性の溶液になる現象を(うゔ)。ミセルやベシク ルなどに代表される分子集合体の工業的な応用は，水難 溶性の反応基質や生体機能物質などを分子集合体内部に 可溶化することにより可能になるといっても過言ではな い。

可溶化は，溶媒に对して難溶性の物質を均一に分散さ

連絡者：酒井夸樹
せて擬似一液相にすることを目的としているので，取り 込んだ被可溶化物質を分子集合体外に放出することまで は意図していない。そこで, 被可溶化物質の集合体への 取り込み，放出を外部からの刺激により可逆的に制御す ることができれば（Fig. 1)，薬物担体への標的指向性 や徐放性の能動的制御や，コロイド次元高次沪過法 ${ }^{3)(4)}$ に用いる界面活性剈の再利用などが可能となる。このよ うな外部刺激の手段としては, 温度, $\mathrm{pH}$, 電場, 電気 化学反応，光などによるスイッチングが考えられる。例 えば，温度変化を利用した制御としては，エチレンオキ シド鎖を親水基として導入した非イオン性界面活性剤の 温度上昇に伴う脱水和を利用する方法 ${ }^{5)}$ ，また分子集合 体がベシクルの場合には，二分子膜の相転移をを利用す る方法などが考えられる。さらに，脂肪酸塩を使用した

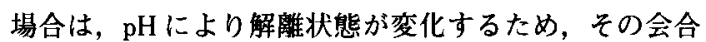




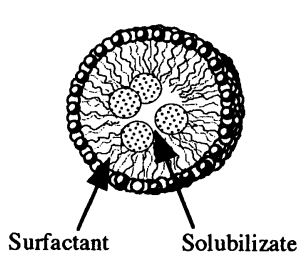

(Solubilization in molecular assemblies)
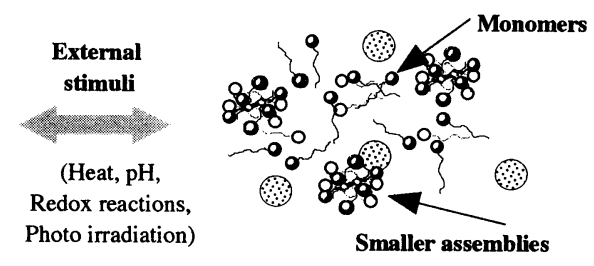

(Release of solubilizates)

Fig. 1 Schematic Illustration of Active Control of Solubilization with External Switching.

体の物性を $\mathrm{pH}$ で制御すること7,8) も試みられている。 さらには, 外部刺激を与える方法として, 電気化学反

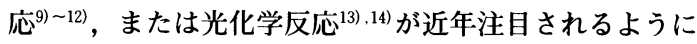
なってきている。電気化学反応は電子の授受を伴うため, イオン化により分子の親水性を変化させることが可能で あり，界面物性のダイナミックな制御が期待できる。ま た, 光による制御は, 第三物質を加える必要のないクリー ンな系として，かつ高速での制御が可能な系として期待 できる。本稿では，このようなコロイド次元分子集合体 の外部刺激による形成制御について, 特に電気化学的な 制御を中心に概説していく。

\section{2 ミセルによる可溶化の電気化学的制御}

\section{$2 \cdot 1$ 酸化・還元部位を有する界面活性剤}

電気化学反応は電子移動を伴う反応であり, 酸化・還 元に伴うイオン化により分子の親水性が大きく変化す る。例えば，脂溶性であり，水にほとんど溶けないフェ ロセンは, 酸化されてフェリシニウムイオン (カチオン) になると水への溶解性が著しく向上する。したがって, 界面活性剤分子にフェロセン部位を導入すると，その酸 化・還元反応により分子の界面物性を電気化学的に制御 することができる。

フェロセン修飾界面活性剤を用いた界面物性の電気化 学的制御に関しては, 佐治らによる報告がある9 ${ }^{910)}$ 。彼 らは，疎水鎖末端にフェロセニル基を修飾した界面活性 剤の物性に及ぼす酸化・還元の影響について検討し， フェロセニル基の酸化により水に対する溶解性が向上し て臨界ミセル濃度 $(\mathrm{cmc})$ が高濃度側にシフトすること, および，この現象を利用してミセルの形成一崩壊を電極 反応により制御できることを示している。鉄イオンが +2 価のとき, フェロセニル基は電気的に中性であり疎 水基として働くのに対して，これを酸化させて +3 価に すると, フェロセニル基は正電荷を帯びて親水基のよう に振る舞うため，分子の親水性が大きく増大する。さら に彼らは，この方法をミセル電解法とよばれる有機薄膜 作製法にも応用している。

この他にも，フェロセンを修飾した非イオン，カチオ
ン界面活性剤の電気化学的挙動に及ぼす界面活性剤濃度 やフェロセニル基の酸化・還元の影響について検討が行 われている11),12)。

\section{$2 \cdot 2$ ミセル形成の電気化学的制御 ${ }^{15)}$}

上述の酸化・還元によるミセルの形成・崩壊の制御は 可逆的に行うことができるため，ミセル内に香料や薬剤 などの被可溶化物質を可溶化させれば, 酸化・還元反応 による可溶化の能動的な制御が可能になるものと考えら れる。そこで我々は, フェロセン修飾界面活性剤の中で も，疎水基の末端にフェロセニル基を有する一鎖型非イ オン界面活性剤に注目し, 分子集合体の形成濃度や形態 に及ぼす酸化・還元の影響, さらに酸化・還元反応を利 用した可溶化の制御を検討した。用いたフェロセン修飾 非イオン界面活性郕は, Scheme 1 に示した11-ferrocenylundecyl polyoxyethylene ether (FPEG) である。

まず, 酸化剤・還元剤の添加による FPEGの化学的 な酸化, あるいは還元の確認を紫外可視吸収スペクトル により行ったところ，FPEG は酸化剤である硫酸セリ ウムの添加により酸化されて $\mathrm{FPEG}^{+}$(酸化体) になり, さらにFPEG ${ }^{+}$は還元剤である次亜硫酸ナトリウムの添 加により再還元されて FPEG（還元体）になることを 確認した。

次に, 還元体, 酸化体, 再還元体の界面活性を調べる ために，表面張力一濃度曲線を測定した（Fig. 2)。還 元体 $(\bigcirc)$, 酸化体 (O), 再還元体 (D) のいずれの溶 液の場合も, 表面張力值は界面活性剤濃度の増加に伴い 減少し, ある濃度で屈曲を示したあと一定となった。こ れらの屈曲点から求められる FPEGのミセル形成濃度 (cmc）は，フェロセニル基の酸化により $8 \times 10^{-6} \mathrm{~mol} /$ $\mathrm{L}$ から $9 \times 10^{-5} \mathrm{~mol} / \mathrm{L}$ へと高濃度側にシフトし, 再還元

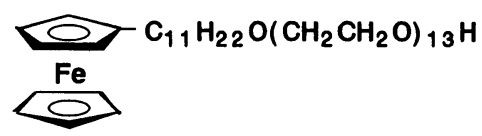

FPEG

11-ferrocenylundecyl polyoxyethylene(13) ether (FPEG)

Scheme 1 Molecular Structure of FPEG. 


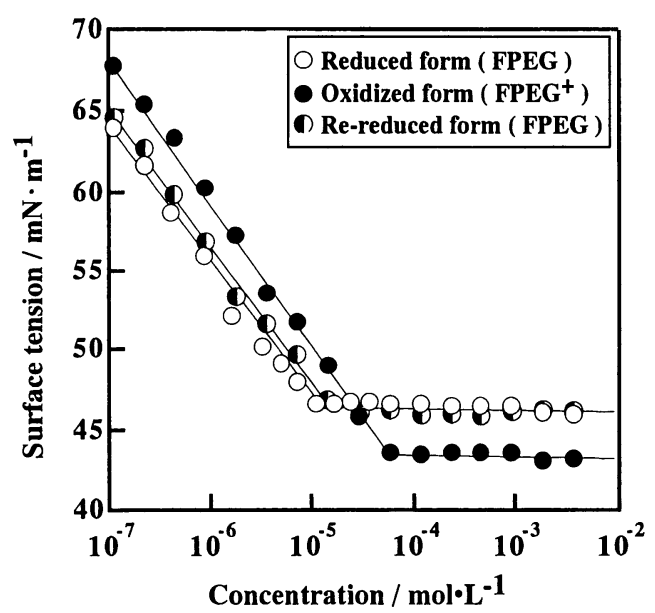

Fig. 2 Relationship between the Surface Tension of FPEG Solutions and the Surfactant Concentration.

により $1 \times 10^{-5} \mathrm{~mol} / \mathrm{L}$ へ再び低濃度側にシフトした。 また, 酸化体の到達最低表面張力値 $(42 \mathrm{mN} / \mathrm{m})$ は, 還 元体の到達最低表面張力值 $(46 \mathrm{mN} / \mathrm{m})$ よりも減少して いる。つまり，フェロセン修飾非イオン界面活性剤は， 酸化体になると分子の親水性がかなり増大するため, ミ セルを形成しにくくなることを示している。

また，困には示していないが，Gibbs の吸着式を用い て気／液界面における FPEG（還元体）一分子当たり の分子占有面積 $A$ を求めたところ ${ }^{16)}, 95 \pm 5 \AA^{2}$ となり, 通常の一鎖型界面活性剤の場合より大きな值となった。 これは, Fig. 3 に示すように, FPEG 分子が還元体で ある場合でさえも，フェロセニル基を気／液界面に近づ けたブリッジ型の配向をすることに起因するものと考え られる。ちなみに, 同様の挙動は FPEG とアルキル鎖 長が同じであり，親水基にアンモニウム塩を持つフェロ セン修飾カチオン界面活性剤 (11-ferrocenylundecyltrimethylammonium bromide (FTMA) ${ }^{17)}$ の場合にも認め られる。

フェロセニル基の酸化・還元によりミセルの粒子径が どのように変化するかを検討するために, $\mathrm{cmc}$ より充分 に高い濃度 $(2 \mathrm{mM})$ において動的光散乱測定を行った ところ, FPEGの平均粒子径は, 還元体では $8 \mathrm{~nm}$, 酸 化体では $3 \mathrm{~nm}$, 再還元体では再び $8 \mathrm{~nm}$ となり，フェロ セニル基の酸化により粒子径が小さくなり, フェロセニ ル基の還元によって再び元の大きさに戻った（Fig. 4)。

さらに, 還元体, 酸化体, 再還元体の水溶液の会合状 態の変化を, サイクリックボルタモグラム $(\mathrm{CV})$ 測定 を用いて電気化学的に検討した。なお, 電気化学測定は, 作用極をカーボン, 対極を白金線, 参照電極を飽和カロ メル電極とする三電極系とし, セルには二室の $\mathrm{H}$ 型セ

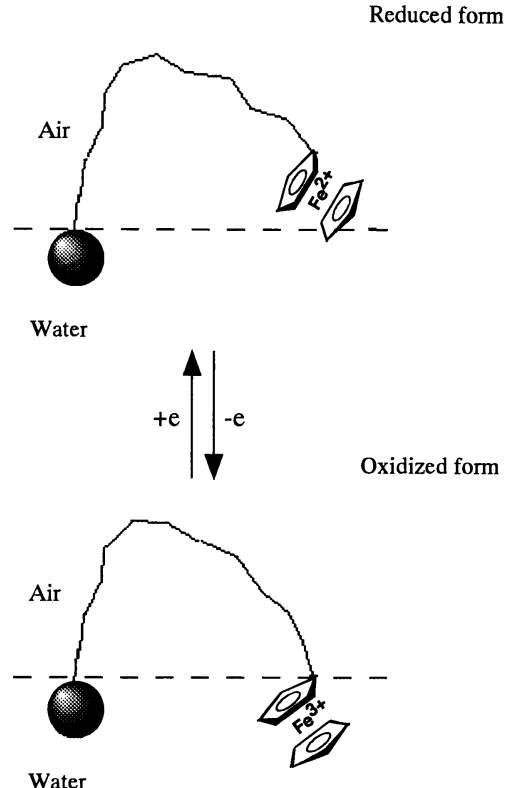

Fig. 3 Conformation Model of FPEG Molecules at the Surface of Aqueous Solutions.
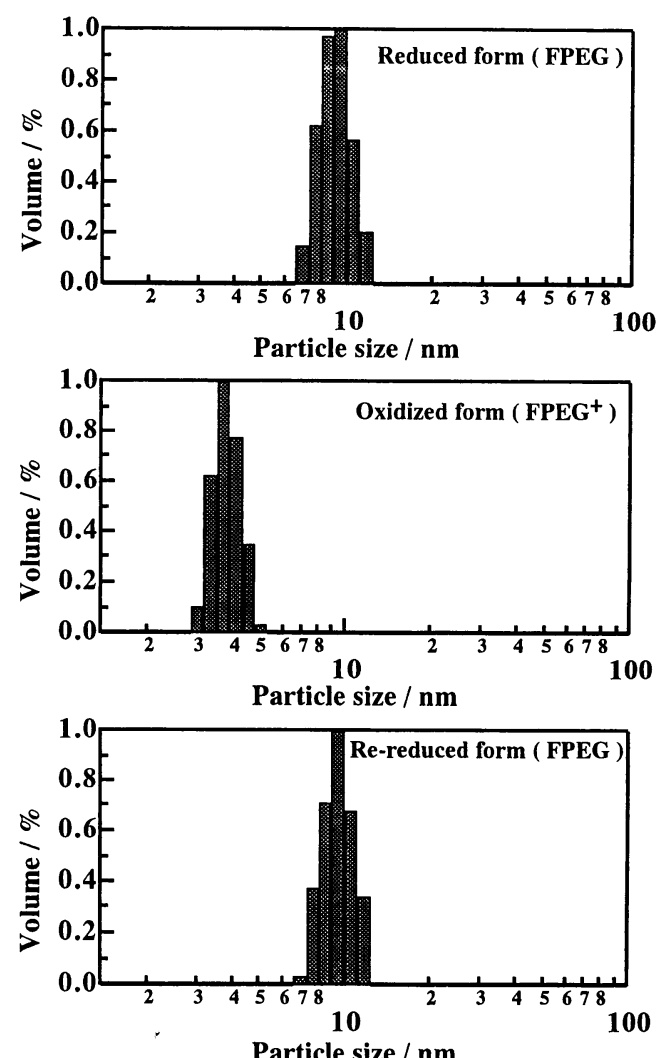

Fig. 4 Particle Size Distribution of $2 \mathrm{mM}$ FPEG Micellar Solutions. 


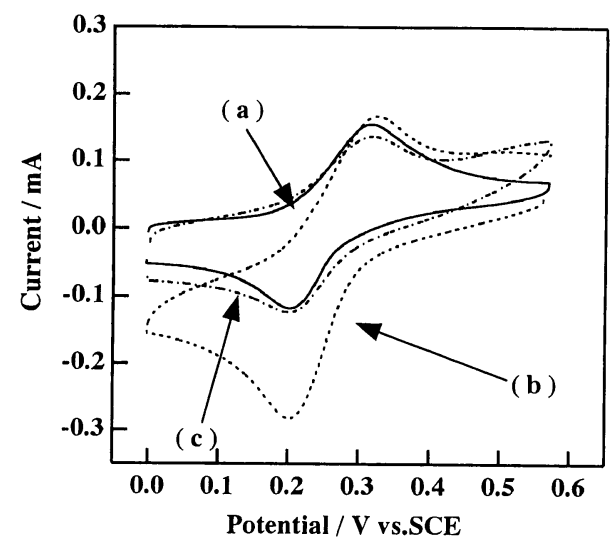

Fig. 5 Cyclic Voltammograms for (a) Reduced Form, (b) Oxidized Form, and (c) Re-reduced Form of FPEG Solutions. Scan rate : $20 \mathrm{mVs}^{-1}$. Working electrode area : $1.57 \mathrm{~cm}^{2}$. Working electrode : glassy carbon electrode. Counter electrode : platinum plate. Reference electrode saturated calomel electrode.

ルを用いた。Fig. 5 (a) には $2 \mathrm{mM} \mathrm{FPEG}$ 水溶液の CV を，(b)には（a）の溶液を硫酸セリウムで酸化した溶液 の CV を，(c) には (b) の溶液を次亜硫酸ナトリウムで 再還元した際の CV を示す。Fig. 5 より, 酸化後の溶液 の CV (b) におけるピーク電流值は, 酸化前より大きく なっていることが分かる。ここで, 濃度一定条件下では, 電流值は反応種の搪散係数の平方根に比例する ${ }^{18)}$ ことか ら, 硫酸セリウムで酸化後の FPEG の拡散係数は, 酸 化前に比べ増大していることが分かる。これは，酸化体 のミセルが還元体に比べて小さいこと (Fig. 4)，なら びに酸化体の $\mathrm{cmc}$ の方が大きいためにミセルを構成し ている FTMA 分子数が少ないことなどに起因している ものと考えられる。さらに，次带硫酸ナトリウムで還元 した後の溶液のサイクリックボルタモグラム (c) におけ る電流ピークは, 酸化体のものより小さくなっている。 また,このピークは, 還元体の溶液の電流ピーク位置と ほぼ一致し，さらにピーク電流值もほぼ同じであったこ とから, 再還元体の溶液では酸化体の溶液より会合体が 大きくなっていることが示唆された。

これまで述べてきた様に, FPEG 水溶液の物性（表 面張力, 粒子径, 分子占有面積など）はフェロセニル基 の酸化状態の影響を強く受けることが示された。これら の酸化・還元反応に伴う溶液物性の変化を利用すれば, 油性物質のミセル中での可溶化量を電気化学的に可逆制 御できることが期待される。

\section{$2 \cdot 3$ ミセルによる可溶化の電気化学的制御}

FPEG が形成するミセルに, 被可溶化物質としてべ ンゼンを可溶化させ, ベンゼンの可溶化平衡定数 $K$ に
及ぼすフェロセニル基の酸化・還元の影響をへッドス ペース法により検討する。なお, 被可溶化物質のミセルー バルク相間における可溶化平衡定数 $K\left(\mathrm{M}^{-1}\right)$ を(1) 式で定義する ${ }^{19)}$.20)。

$$
K=\frac{X_{\text {org }}}{C_{\text {org }}}
$$

$X_{\text {org }}$ はミセル中の被可溶化物質のモル分率， $C_{\text {org }}$ は ミセルに可溶化されずバルク相に溶存する被可溶化物質 のモル濃度を表している。なお，（1）式の $K$ の值が大 きいほど, 被可溶化物質は分子集合体であるミセル内に 分配（可溶化）されやすいことを表している。

ここで, 可溶化の評価法の一つであるへッドスペース 法について簡単に説明する。Fig. 6 は, サンプルバイ アルを表すモデル困であり，バルク相に溶存している被 可溶化物質 (ベンゼン) はミセル一バルク相間とバルク 一気相間において平衡が成立している。ヘッドスペース 法はこのバルク一気相間の平衡をガスクロマトグラ フィーを用いて測定することにより，ミセル一バルク相 間の可溶化平衡定数 $K$ を算出する方法である。ヘッド スペース法は, 気相中の有機物質濃度の測定から, 平衡 にある液相中の被可溶化物質濃度を算出する方法である ため, 測定対象とする被可溶化物質がある程度揮発性を 持ち, かつ水溶液中にある程度溶解する必要がある。し かし，可溶化溶液がサンプルバイアルに密封されている ので, 可溶化平衡に到達した後も可溶化溶液と気相間の 平衡関係は変化しないことになる。FPEG は酸化・還 元により溶液の状態を変化させるので, サンプルバイア ル内の可溶化溶液の状態を常に一定に保つことが望まし く，ヘッドスペース法を用いるのが最適と考えられる。

まず，水または FPEG 水溶液に種々の濃度のベンゼ ンを添加し, これらの水溶液と平衡状態にあるべンゼン の分圧を測定した。純べンゼンの蒸気压をガスクロマト グラフィーにより測定した後, サンプルバイアル中の試 料溶液と平衡にあるべンゼンの蒸気圧を測定し，（2）

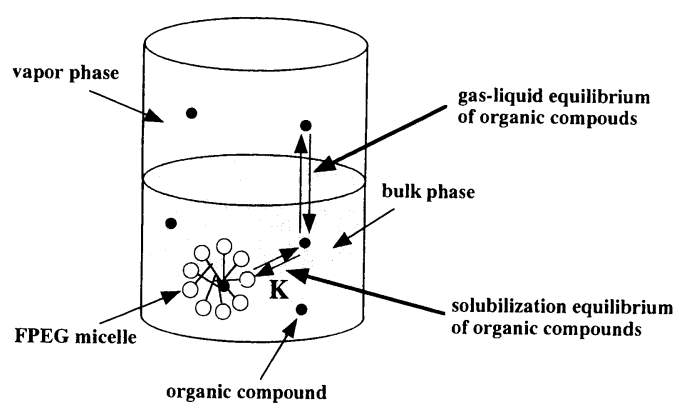

Fig. 6 Schematic Illustration of Distribution Equilibrium of Organic Compounds Among Vapor, Bulk Solution, and Micelles. 
式によりベンゼンの活量 $a$ を求め, さらに $a$ を (3) 式 に代入することによりベンゼンの分圧を求めた。ここで, $P k, P k^{0}$ はそれぞれ試料または純べンゼンのピーク面

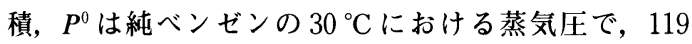
Torr ${ }^{20)}$ である。

$$
\begin{aligned}
& a=\frac{P k}{P k^{0}} \\
& P=P^{0} \cdot a
\end{aligned}
$$

Fig. 7 に，ベンゼン水溶液またはベンゼンを可溶化 させた FPEG 水溶液と平衡にある気相べンゼンの分圧 $(P)$ と, 溶液中のべンゼン濃度 $\left(C_{s o l}\right)$ との関係を示す。 同じべンゼン濃度で比較すると, 可溶化溶液における分 圧はベンゼン水溶液の場合よりも減少している。これは, バルク相中に溶存していたベンゼンがミセルに可溶化さ れたためである。さらに，フェロセニル基の酸化により 分圧が増加しているが，これはミセル中に可溶化されて いたベンゼンの一部がバルク相に放出されたためであ り, 還元により再び分圧が減少したのはバルク相中に溶 存していたべンゼンが再びミセル中に可溶化されたため である。

次に, Fig. 7 の結果を基にベンゼンの可溶化平衡定 数 $K$ の算出を試みる。まず，ベンゼン水溶液と平衡に あるべンゼンの分圧 $(P)$ と, 溶液中の全べンゼン濃度

$\left(C_{s o l}\right)$ との関係をHansen-Miller 式 ${ }^{21}$ にフィッティン グすると（4）式を得る。

$$
P=3.3 C+2.3 \times 10^{-3} C^{2}
$$

これは可溶化されずバルク相に溶存するべンゼンの濃 度とベンゼンの分圧との関係であり, 可溶化溶液の分圧 を（4）式に代入すると，ミセルに可溶化されずバル ク相に溶存するべンゼンの濃度 $\left(C_{\text {org }}\right)$ が算出される。

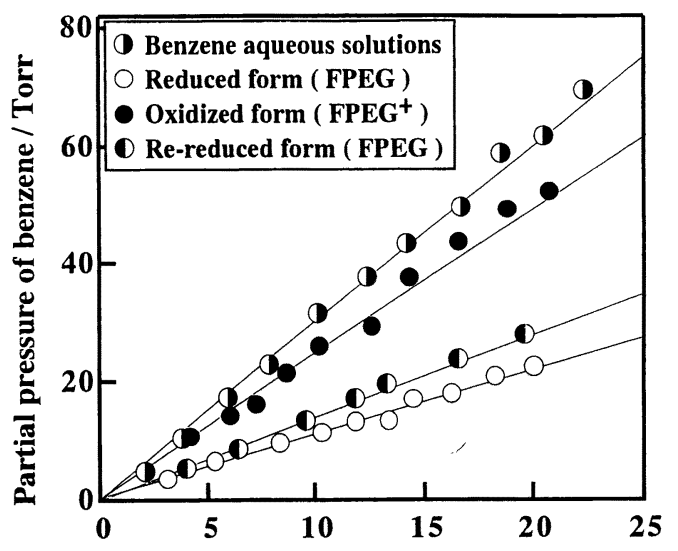

Total concentration of benzene / $\mathbf{m M}$

Fig. 7 Partial Vapor Pressure of Benzene for Aqueous Solutions and $10 \mathrm{mM}$ FPEG Aqueous Solutions as a Function of Benzene Concentration.
また，ミセル中のベンゼンの濃度は, 溶液中のベンゼン の濃度 $\left(C_{\text {sol }}\right)$ からミセルに可溶化されずバルク相に溶 存するべンゼンの濃度 $\left(C_{\text {org }}\right)$ を差し引いたものとして 算出できる。さらに, 還元体, 酸化体, 再還元体のミセ ル形成濃度は表面張力測定の結果より分かっているの で, $X_{\text {org }}$ (5) 式から求められる。

$$
X_{\text {org }}=\frac{\left(C_{\text {sol }}-C_{\text {org }}\right)}{([F P E G]-c m c)+\left(C_{\text {sol }}-C_{\text {org }}\right)}
$$

これらの計算で求められる $X_{\text {org }}$ および $C_{\text {org }}$ を

式に代入すると可溶化平衡定数 $K$ が得られる。

可溶化平衡定数 $K$ と, ミセル内に抢ける被可溶化物 質のモル分率 $X_{\text {org }}$ との間には, 多くの可溶化系に対し て次式が成立することが実験的に知られている22) 25)。

$$
K^{1 / 2}=K_{0}^{1 / 2}-B K_{0}^{1 / 2} X_{\text {org }}
$$

なお, $K^{1 / 2}$ は可溶化平衡定数の平方根, $K_{0}$ は $X_{\text {org }} \rightarrow$ 0 における可溶化平衡定数， $B$ は定数である。そこで, FPEG ミセルにベンゼンを可溶化させた場合の可溶化 平衡定数 $K$ の平方根と, ミセルに可溶化されているべ ンゼンのモル分率 $X_{\text {org }}$ との関係を Fig. 8 に示す。Fig. 8 から明らかなように, $K^{1 / 2}$ 值は $X_{\text {org }}$ の増加に伴いほ ぼ直線的に変化しており，(6) 式の関係が成立するこ とが確認される。

$K^{1 / 2}$ に及ぼす FPEG の酸化・還元の影響に着目する と, 還元体 $(\bigcirc)$, 酸化体 $(\boldsymbol{O})$, 再還元体 $(\boldsymbol{O})$ のいず れの場合も， $K^{1 / 2}$ 值は $X_{\text {org }}$ の增加に伴い減少している。 これはミセル内におけるべンゼンのモル分率が高くなる と，可溶化平衡定数が小さくなることを意味する。界面 活性剤水溶液中における可溶化平衡は, ベンゼンと界面 活性鼡との親和性に依存する。また，ミセル内における ベンゼンのモル分率が増加すると, ミセル内部のベンゼ

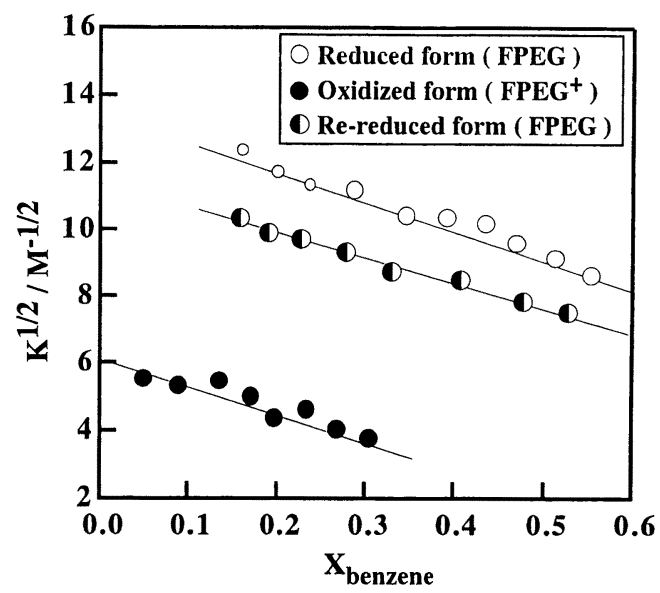

Fig. 8 Dependence of Solubilization Equilibrium Constants $\left(\mathrm{K}^{1 / 2}\right)$ of Benzene in FPEG Micelles on Intramicellar Mole Fraction ( $\mathrm{X}_{\text {org }}$ ). 
ンは純液体状態に近づく。つまり，ミセル内におけるべ ンゼンのモル分率の增加（ $X_{\text {org }}$ の增加）に伴いミセル 内におけるべンゼンと界面活性郕との親和性が低下する ため, $K^{1 / 2}$ 值が減少したものと考えられる。

また，フェロセニル基の酸化に伴い $K^{1 / 2}$ の值は著し く減少している。これは, 酸化によりべンゼンが可溶化 されにくくなり，可溶化されていたべンゼンの一部がミ セルからバルクへと放出されたためである。さらに, フェ ロセニル基の還元に伴い $K^{1 / 2}$ の值は再び増加した。こ れは，還元により再びべンゼンは可溶化されやすくなる ため，バルク相中に溶存していたべンゼンがミセル内へ 再び可溶化されたものと考えられる。つまり，FPEG の酸化・還元反応を利用することにより，ミセル中への 油性物質の可溶化を能動的に制御できることが示唆され た。

\section{$2 \cdot 4$ 可溶化の電気化学的制御に影響を及ぼす因子 \\ $2 \cdot 4 \cdot 1$ 被可溶化物質の物性の影響}

FPEG ミセル内に可溶化させる油性物質の種類を変 化させて，酸化・還元反応による被可溶化物質の放出効 率に及ぼす油性物質の物性の影響を検討することにす る。

油性物質として, ベンゼンより疎水性が高いエチルベ ンゼンを用いた場合の可溶化平衡定数に及ぼすフェロセ ニル基の酸化の影響を Fig. 9 に示す。ベンゼンの場合 と同様に, 可溶化平衡定数はフェロセニル基の酸化に伴 い減少し, 再還元に伴い再び増大するという結果が得ら れている。さらに，酸化・還元に伴う可溶化平衡定数 の変化はべンゼンより大きく, 油性物質の電気化学的な 放出制御がより高効率で行えることが分かる。これは，

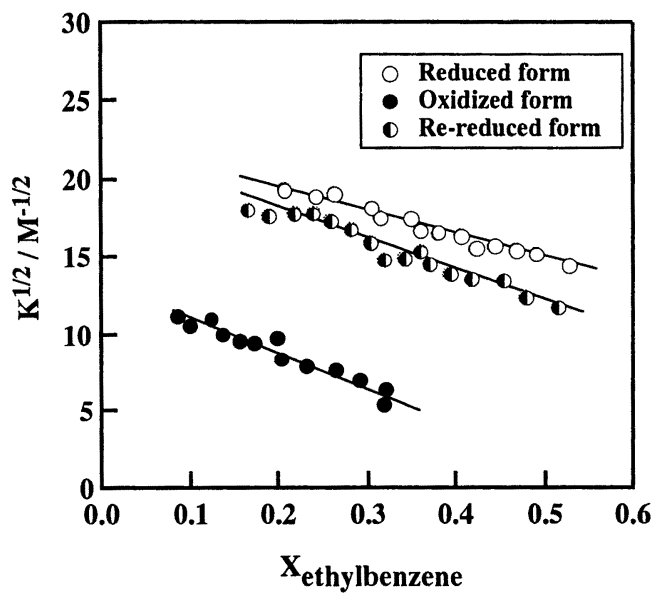

Fig. 9 Dependence of Solubilization Equilibrium Constants $\left(\mathrm{K}^{1 / 2}\right)$ of Ethylbenzene in FPEG Micelles on Intramicellar Mole Fraction $\left(\mathrm{X}_{\mathrm{org}}\right)$.
疎水性の高いエチルベンゼンは，ミセルのコア（炭化水 素鎖）部分に可溶化されるため，酸化によるミセルの疎 水性領域の減少の影響を受けやすいためであると考えら れる。

一方，極性基を有する 2-フェニルエチルアルコール (ベンゼンより親水性が高い) は，主にミセルの POE 鎖部分に可溶化されることから，FPEGミセルの酸化 による疎水性領域减少の影響を受けにくいと考えられる が，ベンゼンやエチルベンゼンと同様の傾向を示すこと が分かった。このことより, FPEGミセルの疎水部以 外に可溶化される油性物質を用いた場合でも，フェロセ 二ル基の酸化還元反応により油性物質の放出制御が可能 であることが分かる。

\section{$2 \cdot 4 \cdot 2$ 酸化・還元手法の影響}

酸化剛・還元凨の添加により FPEG 分子中のフェロ 七ニル基の酸化・還元を，行う場合，測定系に第三物質 を添加する必要があり，これが溶液状態に影響を及ぼす ことが避けられないという問題がある。そこで, FPEG の酸化・還元を白金電極を用いて電極反応により行うこ とを試みる。

FPEG の電極酸化は，還元体の溶液を $\mathrm{N}_{2}$ ガスを流し ながら， +0.6 V vs. SCEで 21 時間定電位電解するこ とにより行った。再還元体の溶液の調製は，酸化体の溶 液を $0.0 \mathrm{~V}$ vs. SCE で 21 時間定電位電解することによ り行った。なお, 電解は作用極を白金板, 対極を白金線, 参照電極を飽和カロメル電極とする三電極系で行い，七 ルには二室の $\mathrm{H}$ 型セルを用いた。また，支持塩として， $0.1 \mathrm{M} \mathrm{Li}_{2} \mathrm{SO}_{4}$ を用いた。

FPEG ミセルにベンゼンを可溶化させた場合の可溶 化平衡定数 $K$ の平方根とミセルに可溶化されているべ ンゼンのモル分率 $X_{\text {org }}$ との関係を Fig. 10 に示す。 $K^{1 / 2}$ に及ぼす FPEG の酸化・還元の影響に着目すると，ま ず還元体，酸化体，再還元体のいずれの場合も， $K^{1 / 2}$ 值 は $X_{\text {org }}$ の増加に伴い減少している。また, フェロセニ ル基の酸化に伴い $K^{1 / 2}$ の值は著しく減少している。こ れは酸化によりベンゼンが可溶化されにくくなり，可溶 化されたベンゼンの一部がミセルからバルクへと放出さ れたためである。さらに，フェロセニル基の還元に伴い $K^{1 / 2}$ の值は再び増加したことから，還元により再びベン ゼンは可溶化されやすくなり，バルク相中に溶存してい たベンゼンはミセルへ再び可溶化されたと考えられる。 また, いずれの可溶化溶液の $K^{1 / 2}$ 值も支持電解質を添 加する前より增加し, 可溶化等温線の傾きも変化してい る。これは, 支持電解質の添加によりミセル会合数が増 加し, 所定温度でのベンゼンの可溶化量が増大したため である。

\section{$2 \cdot 4 \cdot 3$ 界面活性剤親水基の影響26)}

さらに，非イオン性の FPEG とは親水基部分の構造 


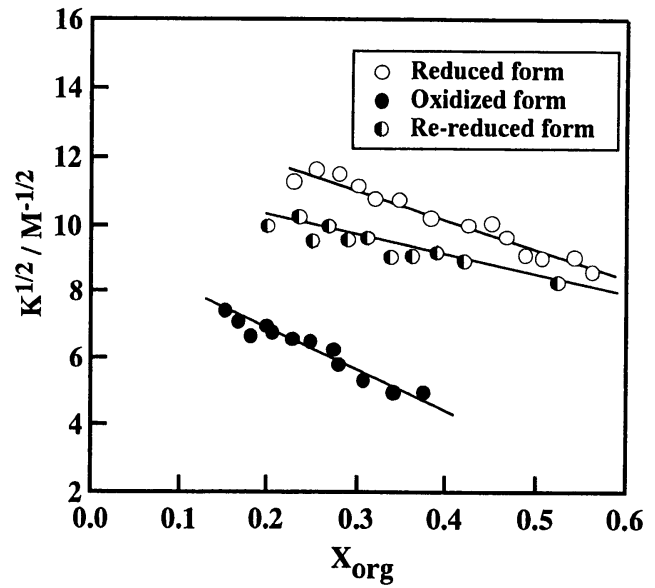

Fig. 10 Dependence of Solubilization Equilibrium Constants $\left(\mathrm{K}^{1 / 2}\right)$ of Benzene in FPEG Micelles on Intramicellar Mole Fraction $\left(\mathrm{X}_{\mathrm{org}}\right)$. FPEG was oxidized and re-reduced by electrolysis using a glassy carbon electrode.

が異なる，カチオン性の ferrocenylundecyltrimethylammonium bromide (FTMA) を用いて, 同様の被可溶化 物質の放出制御を試みた。FTMAの場合，4級アンモ ニウム基の存在により還元体の分子も正電荷を帯びてお り，これが酸化されると 2 荷電荷を帯びることになる。 また, FPEG と同様に, 酸化体では分子の両末端がイ オン化されるために，二親水基界面活性剤と同様のボラ フォーム型の分子構造を取ることが知られている。

Fig. 11 に, FTMA ミセル内へのベンゼンの可溶化平 衡定数に及ぼすフェロセニル基の酸化・還元の影響を示

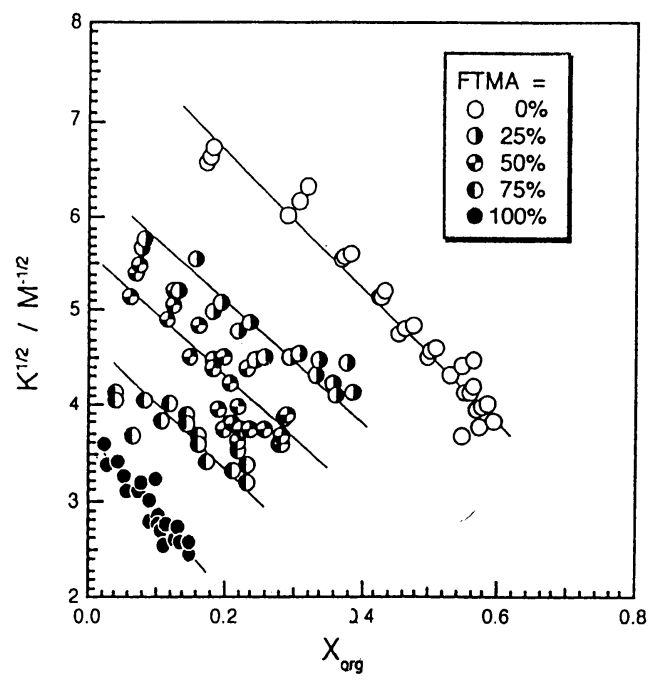

Fig. 11 Dependence of Solubilization Equilibrium Constants $\left(\mathrm{K}^{1 / 2}\right)$ of Benzene in Cationic FTMA Micelles on Intramicellar Mole Fraction $\left(\mathrm{X}_{\mathrm{org}}\right)$.
す。FPEGの場合と同様に，酸化体が形成するミセル による可溶化平衡定数は還元体の場合より小さくなり， ミセル内に可溶化されていたベンゼンが酸化によりバル ク溶液中に放出されることが分かる。しかし，カチオン 性の FTMA が形成するミセルは非イオン性の FPEG よ りも小さいので, 可溶化されるべンゼンの絶対量も小さ くなってしまう。したがって，FPEGを用いた方が被 可溶化物質のダイナミックな制御が可能であると考えら れる。

\section{3 ベシクルの電気化学的形成制御および可溶化 への応用 ${ }^{26,27)}$}

ミセルの形成一崩壊を外部刺激により制御する試み は, 前節で述べた電気化学的な検討をはじめとして多数 行われている。電気化学な手法の他にも, 光異性化反応 を利用した光化学的方法 ${ }^{13)}$,14), また, 温度や $\mathrm{pH}$ などに よる制御法(5) 8) も報告されている。

一方，二分子膜構造を有するべシクルに関しては，二 分子膜内部に水難溶性分子を可溶化することが可能であ り, また可溶化能や可溶化平衡定数はミセルよりも大き いことも報告されている ${ }^{28)}{ }^{29)}$ が，その形成を外部刺激に より可逆的に制御し，被可溶化物質の放出を制御する試

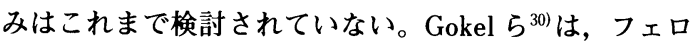
セニル基修飾界面活性㓮を分散させた溶液に超音波処理 を行って調製したベシクルが, 電解酸化によりモノマー に分解すると報告しているが，一度崩壊させたべシクル を還元して再形成させることはできない。これは，通常 のベシクルがミセルと異なり熱力学的に非平衡な系であ るからである。また, 国武ら ${ }^{14)}$ は, アゾベンゼンを修飾 した両親媒性分子によるべシクル調製に関して精力的な 検討を行い, 光異性化による膜透過性の変化などを調べ ているが, ベシクルの形成そのものを光照射により制御 するには至っていない。

ところで，カチオン性とアニオン性の界面活性剤を所 定の濃度・割合で混合するとべシクルが自発的に形成す

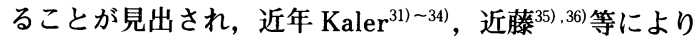
勢力的に研究されている。そこで我々は, 電気化学反応 により界面化学的作用が可逆的に変化するカチオン界面 活性剤を，アニオン界面活性剤と混合することにより自 発ベシクルを調製し，ベシクルの形成および崩壊を電気 化学反応により可逆的に制御することを試みている ${ }^{37)}$ 。

電気化学活性なカチオン界面活性剤として FTMA (11-ferrocenylundecyltrimethylammonium bromide, 以 後還元体を $\mathrm{FTMA}^{+}$, 酸化体を $\mathrm{FTMA}^{2+}$ と略す) を用い, これを種々の濃度・組成でアニオン性の SDBS (sodium dodecylbenzenesulfonate）と混合し，溶液の相状態を微 分干涉光学顕微鏡により観察した。得られた FTMA ${ }^{+}$ /SDBS/水系の $25^{\circ} \mathrm{C}$ における三角相図を Fig. 12 に示 
す。図中の領域 M は等方性溶液（ミ七几溶液）, 領域 I は沈殿生成領域を表している。これらの領域以外ではラ メラ液唱が観察された（領域 V+L，V)。中でも領域 V においては，Fig. 13 (a)の写真に示すようなドーナッ 状の分子集合体が観察され，ベシクルが自発的に形成し ていることが分かる（透過型電子顕微鏡による観察でも 確認)。なお，グルコース透析法で求められたべシクル の保持効率は約 $3 \%$ であった。

$\mathrm{FTMA}^{+} / \mathrm{SDBS}$ /水の組成を, Fig. 12 の領域 Vのほ ぼ中央である A 点 $\left(\mathrm{FTMA}^{+}: \mathrm{SDBS}:\right.$ 水 $=0.7: 0.3$ : $99 \mathrm{wt} \%$ ）に固定して，ベシクル分散水溶液の定電位酸 化および還元を行い，酸化・還元反応に伴う相状態の変 化について検討した。白金電極の電位を+0.5V vs. SCEに設定して溶液 A を酸化したときの溶液の状態を 顕微鏡観察すると（Fig. 13 (b))，酸化前に観察された ミクロンオーダーの大きさのベシクルは消失しているこ とが分かる。さらに，この溶液を $0.0 \mathrm{~V}$ vs. SCEで再
摆元すると、ベシクルが再形成する。(Fig. 13 (c))。つ まり,FTMA/SDBS/水系で電気化学反応を行うと, 心゙ シクルの形成一崩壊を可逆的に制御できることになる。

異種電荷を有する界面活性剂分子の混合によりベシク ルが自発形成する機構については，未だ統一的な見解が 得られていないのが現状である。しかし，界面活性威分 子の幾何学的精造がシリンダー構造に近く, さらに分子 の親水性が適当な条件を満たしている時にのみべシクル が自発形成すると考えられている32)。一鎖型カチオン性 の $\mathrm{FTMA}^{+}$(還元型) と一鎖型アニオン性の SDBS が 形成する疑似二鎖型界面活性剤は，これらの条件を满た しているため, ベシクルを自発的に形成すると考えられ る。一方, $\mathrm{FTMA}^{+}$のフェロセニル基が酸化されてフェ リシニウムイオンが生じると, 分子の親水性が著しく增 加するため，ベシクルの形態を保てなくなり，混合ミ七 ルなどの小さな分子集合体を形成するものと思われる。

以上述べたように，カチオン/アニオン混合界面活性

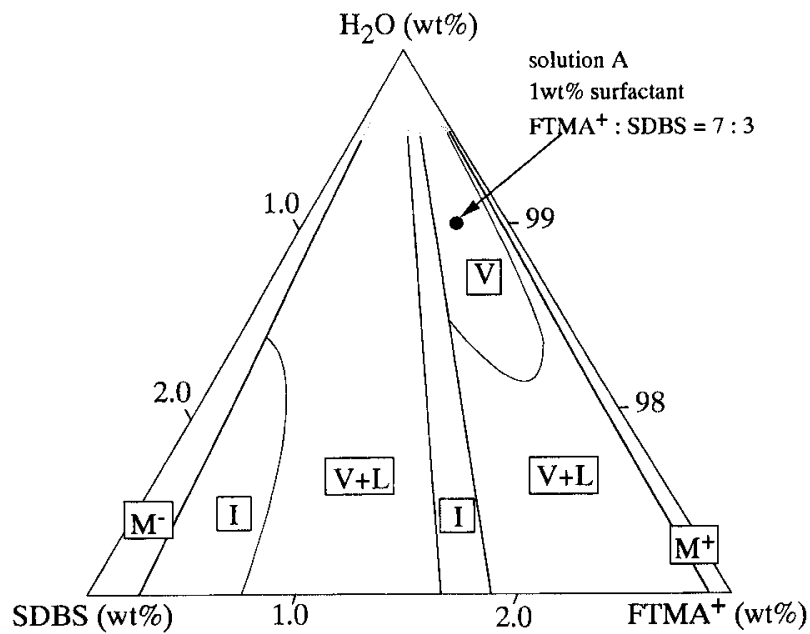

Fig. 12 Ternary Phase Diagram for FTMA ${ }^{+} / \mathrm{SDBS} / \mathrm{H}_{2} \mathrm{O}$ at $25^{\circ} \mathrm{C}$. One-phase regions are vesicles $(\mathrm{V}), \mathrm{FTMA}^{+}-$ rich micelles $\left(\mathbf{M}^{+}\right)$, and SDBS-rich micelles $\left(\mathbf{M}^{-}\right)$. Two-phase region is $\mathrm{V}$ and lamellar phase $(\mathrm{V}+\mathrm{L})$. Three-phase region is $\mathrm{V}, \mathrm{L}$, and precipitate (I).

(a)

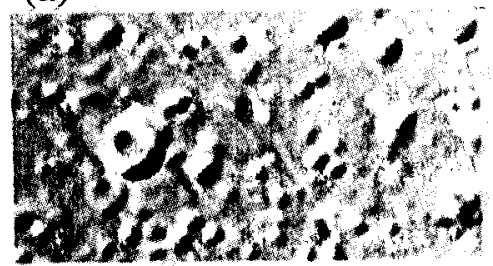

(b)

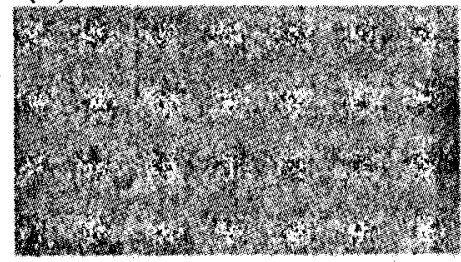

(c)

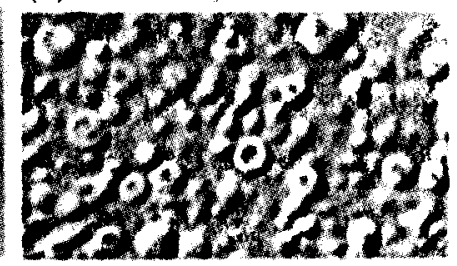

Fig. 13 Differential Interference Optical Micrographs of FTMA (0.7 wt $\%)$ /SDBS (0.3 wt $\%)$ Mixed Aqueous Solution, (a) as prepared (reduced form), (b) oxidized form, (c) re-reduced form. 
剤水溶液で形成されるべシクルの崩壊と再形成を，フェ ロセニル基の酸化・還元反応により能動制御できること が分かった。このベシクル二分子膜内部に油性物質を可 溶化させることにより, ベシクル内に可溶化された物質 の放出速度を電気化学的に制御することも可能であるの で，現在検討を行っている。

\section{4 おわりに}

界面活性剤が形成するミセル・ベシクルなどの分子集 合体内への油溶性物質の可溶化を, 電気化学反応を用い て可逆的に制御する試みを中心に紹介してきた。我々は, アゾベンゼンを修飾した光応答性を有する界面活性剤を 用いて，ミセルおよびベシクルの形成と崩壊 ${ }^{38)}$ ，さらに は可溶化 ${ }^{39)}$ 光によりスイッチングすることも試みてい る。これらの研究が, ドラッグデリバリーシステムにお ける薬剤の放出速度の制御や, 香料などの香粧品の揮発 性の制御などへの応用の端緒になれば幸いである。

\section{謝 辞}

本稿で紹介させていただいた我々の成果は, 東京理科 大学理工学部の柿澤恭史氏, 今村 仁氏, 武井拓人氏の 協力で得られたものである。ここに深く感謝いたします。 (受付 : 2000 年 5 月 10 日, 受理 : 2000 年 6 月 19 日)

\section{文献}

1) M. J. Rosen, "Surfactants and Interfacial Phenomena”, 2nd ed., Wiley Interscience, New York (1989) p. 170.

2) C. S. Dunaway, S. D. Christian, J. F. Scamehorn, "Solubilization in Surfactant Aggregates", S. D. Christian, J. F. Scamehorn, ed., Marcel Dekker, New York (1995).

3) J. H. Scamehorn, J. H. Harwell, "Surfactant-Based Separation Processes", Marcel Dekker, New York (1989).

4) 阿部正彦, 近藤行成, 材料技術, 10, 275 (1992).

5) P. Alexandridis, Current Opinion in Colloid \& Interface Sci. 2, 478-489 (1997).

6) Y. Kondo, N. Yoshino, T. Shinohara, H. Sakai, M. Abe, J. Jpn. Oil Chem. Soc., 46, 165 (1997).

7) D. P. Cistola, D. Atkinson, J. A. Hamilton, D. M. Small, Biochemistry, 25, 2804 (1986).

8) D. P. Cistola, J. A. Hamilton, D. Jackson, D. M. Small, Biochemistry, 27, 1881 (1988).

9) T. Saji, K. Hoshino, Y. Ishii, M. Goto, J. Am. Chem. Soc., 107 ,6865 (1985).

10) T. Saji, K. Hoshino, Y. Ishii, M. Goto, J. Am. Chem. Soc., 113, 450 (1991).

11) K. Tajima, T. Huxur, Y. Imai, I. Motoyama, A. Nakamura, M. Koshinuma, Coloids Surf. A, 94, 243
(1995).

12) Y. Takeoaka, T. Aoki, K. Sanui, N. Ogata, M. Watanabe, Langmuir, 12, 487 (1996).

13) T. Hayashita, R. Kurosawa, T. Miyata, K. Tanaka, M. Igawa, Colloid Polymer Sci., 272, 1611 (1994).

14) T. Kunitake, Y. Okahata, M. Shimomura, S. Yasunami, K. Takarabe, J. Am. Chem. Soc, 103, 5401 (1981).

15）酒井秀樹, 武井拓人, 柿澤恭史, 近藤行成, 阿部 正彦, 日本油化学会誌, 47, 1337 (1998).

16）中垣正幸, 表面状態とコロイド状態, 東京化学同 人 (1974), p. 101.

17) B. S. Gallardo, K. L. Metcafe, N. L. Abbott, Langmuir, 12, 4116 (1996).

18) A. J. Bard, L. R. Faulkner, Electrochemical Methods, Wiley, New York (1980), p. 136.

19) H. Uchiyama, S. D. Christian, J. F. Scamehorn, M. Abe, K. Ogino, Langmuir, 7, 95 (1991)

20) C. L. Yaws, Handbook of vapor pressure, volume 2, Gulf Publishing Co. (1994), p. 388.

21) R. S. Hansen, F. A. Millar, J. Phys. Chem., 58, 193 (1954).

22) M. Abe, K. Mizuguchi, Y. Kondo, K. Ogino, H. Uchiyama, J. F. Scamehorn, E. E. Tucker, S. D. Christian, J. Colloid Interface Sci., 160, 16 (1993).

23) Y. Kondo, M. Abe, K. Ogino, H. Uchiyama, J. F. Scamehorn, E. E. Tucker, S. D. Christian, Langmuir, 9, 899 (1993)

24) H. Uchiyama, S. D. Christian, J. F. Scamehorn, M. Abe, K. Ogino, Langmuir, 7, 95 (1991).

25) B. H. Lee, S. D. Christian, E. E. Tucker, J. F. Scamehorn, Langmuir, 6, 230 (1990).

26) Y. Kakizawa, H. Sakai, T. Saji, N. Yoshino, Y. Kondo, M. Abe, J. Jpn. Soc. Colour Mat., 72, 78 (1999).

27) Y. Kakizawa, H. Sakai, K. Nishiyama, H. Shoji, Y. Kondo, N. Yoshino, M. Abe, Langmuir, 12, 921 (1996).

28) L. van Bloois, D. D. Decker, D. J. A. Crommelin, Acta Pharm. Technol., 33, 136 (1987).

29) Y. Kondo, M. Abe, K. Ogino, H. Uchiyama, J. F. Scamehorn, E. E. Tucker, S. D. Christial, Langmuir, 9, 899 (1993).

30) L. F. Echegoyen, H. K. Yoo, G. W. Gatto, L. Gokel, L. Echegoyen, J. Am. Chem. Soc., 111, 2440 (1989).

31) E. W. Kaler, A. K. Murthy, B. E. Rodriguez, J. A. N. Zasadzinski, Science, 245, 1371 (1989).

32) E. W. Kaler, K. L. Herrington, K. Murthy, J. A. N. Zasadzinski, J. Phys. Chem., 96, 6698, (1992).

33) K. L. Herrington, E. W. Kaler, D. D. Miller, J. A. Z. Zasadzinski, S. Chiruvolu, J. Phys. Chem., 97, 13972 (1993).

34) S. Chiruvolu, J. N. Israelachvili, E. Naranjo, Z. $\mathrm{Xu}$, J. A. Zasadzinski, E. W. Kaler, K. L. 
Herrington, Langmuir, 11, 4256 (1995).

35) Y. Kondo, H. Uchiyama, N. Yoshino, K. Nishiyama, M. Abe, Langmuir, 11, 2380 (1995).

36) 近藤行成, 内山浩孝, 西山勝廣, 渡辺 建, 好野 則夫, 阿部正彦, 材料技術, 12, 314 (1994).

37) H. Sakai, H. Imamura, Y. Kakizawa, M. Abe, Y.
Kondo, N. Yoshino, J. H. Harwell, Denki Kagaku, 65, 669-673 (1997).

38) H. Sakai, A. Matsumura, T. Saji, M. Abe, J. Phys. Chem. B, 103, 10737-10740 (1999).

39) 折原洋一, 酒井秀樹, 阿部正彦, 未公表データ. 


\title{
[総説]
}

\section{可溶化の電気化学的制御}

\author{
酒 井 秀 樹*1,*2 . 阿 部 正彦*1,*2 \\ *1 東京理科大学理工学部工業化学科 \\ （テ278-8510 千葉県野田市山崎 2641） \\ *2 東京理科大学界面科学研究所 \\ （T162-8601 東京都新宿区神楽坂 1-3）
}

界面活性剂が形成するコロイド次元分子集合体による油性物質の可溶化が，フェロセン修飾界面活性剂の電気 化学反応を用いて能動的かつ可逆的に制御された。フェロセン修飾非イオン界面活性剂（11-ferrocenylundecyl polyoxyethylene ether : FPEG) が形成するミセルに対する芳香族炭化水素の可溶化平衡定数 (K) は, FPEG 分子 のフェロセニル基の酸化により隇少し, さらにその再還元により再び増大した。このことより, ミセル内への油 性物質の可溶化量を電気化学反応により可逆的に制御できることが分かった。さらに, フェロセン修飾カチオン 界面活性剂 (FTMA) とアニオン界面活性剤 (SDBS) の混合系におけるベシクルの電気化学的な形成制御と, その 可溶化への応用についても検討を行った。

（連絡者：酒井秀樹） Vol.49, No.10, 1279 (2000) 